\title{
FORMULASI SURIMI IKAN PATIN DAN PUREE WORTEL YANG BERBEDA TERHADAP MUTU PROKSIMAT NUGGET IKAN
}

\author{
Fitra Mulia Jaya, Indah Anggraini Yusanti \\ Program Studi Ilmu Perikanan, Fakultas Perikanan, \\ Universitas PGRI Palembang \\ Email :F_Muliajaya@yahoo.co.id \\ Received February 2018, Accepted March 2018
}

\begin{abstract}
ABSTRAK
Pemanfaatan surimi ikan Patin (Pangasius hypopthalmus) menjadi produk siap saji seperti nugget belum maksimal dikarenakan informasi tentang kandungan gizi dan inovasinya masih terbatas sehingga masyarakat tidak tertarik untuk memanfaatkan surimi ikan Patin menadi produk yang bernilai tambah. Metode yang digunakan dalam penelitian ini adalah metode eksperimen dengan rancangan acak lengkap meliputi faktor yang terdiri dari 5 perlakuan formulasi surimi ikan patin dan Puree wortel yaitu SW $1: 100 \%$ Surimi, SW $2: 90$ Surimi dan 10\% Puree Wortel, SW $3: 80$ Surimi dan 20\% Puree Wortel, SW 4 : 70 Surimi dan 30\% Puree Wortel, SW $5: 60$ Surimi dan 40\% Puree Wortel yang diulang sebanyak 3 kali. Hasil analisa didapatkan perlakuan nugget dengan formulasi surimi $80 \%$ Surimi dan 20\% Puree Wortel (SW3) merupakan perlakuan terbaik berdasarkan nilai kadar kadar air 60,86\%, kadar abu 2,13\%, kadar lemak $1,31 \%$ dan kadar protein $6,33 \%$.
\end{abstract}

Kata Kunci : Nugget, Puree Wortel, Surimi, Proksimat

\begin{abstract}
The utilization of Patin fish surimi (Pangasius hypopthalmus) become the instant products such as nugget has not been maximized because the information about the content of nutrition and innovation is still limited. So, the people are not interested in taking the advantages of surimi of Patin to the best quality products. The method of this research was experimental method with complete randomized design including factors consisting of 5 treatments of surimi catfish and carrot Puree formulation, those were SW 1: 100\% Surimi, SW 2: 90 Surimi and 10\% Puree Carrot, SW 3: 80 Surimi and 20\% Puree Carrots, SW 4: 70 Surimi and 30\% Puree Carrots, SW 5: 60 Surimi and 40\% Puree Carrots repeated 3 times. The result of this research obtained by nugget treatment with surimi was $80 \%$ Surimi and $20 \%$ Puree Wortel (SW3) formula was the best treatment based on
\end{abstract}


moisture content was $60.86 \%$, ash content was $2.13 \%$, fat content was $1.31 \%$ and protein content was $6.33 \%$.

Keywords : Nugget, Puree Wortel, Surimi, Proximat

\section{PENDAHULUAN}

Nugget ikan termasuk ke dalam salah satu bentuk produk beku siap saji yang banyak disukai oleh masyarakat karena dapat memperpanjang umur simpan dan meningkatkan harga jual. Nugget diolah dari daging giling, diberi penambahan bumbu, dicetak kemudian dilumuri dengan tepung roti pada bagian permukaannya dan digoreng (Syamsir, 2008). Bahan utama pembuatan nugget biasanya berasal dari bahan pangan hewani yaitu daging ayam, daging sapi, dan ikan. Selain terbuat dari daging dan ikan, nugget juga dapat dibuat dari sayuran. (Alamsyah, 2007).

Salah satu jenis ikan yang dapat dimanfaatkan dalam pembuatan nugget yaitu ikan Patin. Patin merupakan ikan air tawar yang tingkat

ketersediaannya cukup tinggi yaitu $52 \%$ dari total produksi ikan patin secara nasional yang berasal Sumatera Selatan, hal ini dapat dilihat pada pada angka produksi ikan Patin di Sumatera Selatan tahun 2012 yaitu sejumlah 117.040,00 ton/tahun (DKP Sumatera Selatan, 2013).

Di Sumatera selatan, produk olahan dari ikan patin masih sebatas masakan tradisional, hal ini dikarenakan adanya kandungan lemak pada daging ikan Patin yang menyebabkan warna yang agak kekuningan dan mengambat pembentukan gel sehingga produk yang dibuat dari ikan Patin teksturnya tidak kenyal.

Menurut Kristanti (2014), agar produk yang dibuat dari ikan Patin mempunyai gelasi yang bagus, maka dapat digunakan dilakukan pencucian (leaching) terhadap daging ikan Patin tersebut untuk menghilangkan lemak dari daging yang menghambat terbentuknya gelasi. Perlakukan pencucian (leaching) pada daging ikan sering di sebut Surimi. Surimi dibuat dari daging ikan giling yang telah diekstraksi dengan air yang diberi bahan anti-denaturasi, lalu dibekukan. Surimi merupakan produk antara atau bahan-bahan baku dasar dalam pembutan komaboko (produk gel ikan), sosis, fish nugget, ikan dan lain-lain. Selain itu, surimi juga dapat menjadi bahan baku untuk menjadi produk lain seperti empek, empek, otak-otak, bakso dan kripik ikan.

Pada umumnya bahan baku nugget berasal dari daging yang telah digiling. Dalam penelitian ini peneliti menambahkan sayuran berupa Puree wortel sehingga produk nugget yang dihasilkan lebih bervariasi bukan hanya penampilan yang menarik tetapi juga kandungan gizi yang lebih baik.

Berdasarkan uraian diatas penulis tertarik sehingga melakukan penelitian tentang "Formulasi Surimi Ikan Patin (Pangasius hypopthalmus) dan Puree Wortel yang Berbeda Terhadap Mutu Proksimat Nugget Ikan”. 
Tujuan dari penelitian ini adalah mendapatkan formula nugget dengan kandungan gizi yang terbaik.

\section{MATERI DAN METODE}

\section{Materi Penelitian}

Materi yang digunakan dalam penelitian meliputi Ikan Patin (Pangasius hypopthalmus) yang dibeli di Pasar Induk Jakabaring Palembang. Ikan dibeli pada pagi hari, Wortel (Daucus carota) dan bahan pendukung lainnya seperti tepung tapioka.

\section{Metode Penelitian}

Metode yang digunakan dalam penelitian ini adalah metode eksperimen Rancangan Acak Lengkap (Hanafiah, 2010 ). Perlakuan dalam penelitian ini terdiri dari satu faktor yaitu yaitu penambahan Puree wortel, yang terdiri dari 5 perlakuan yang diulang sebanyak 3 kali. Masingmasing perlakuan sebagai berikut :

SW1 : $100 \%$ (Surimi)

SW2: $90 \%$ (Surimi) dan 10\% (Puree Wortel)

SW3: $80 \%$ (Surimi) dan 20\% (Puree Wortel)

SW $4: 70 \%$ (Surimi) dan 30\% (Puree Wortel)

SW5: 60\% (Surimi) dan 40\% (Puree Wortel)

Adapun parameter yang diamati dalam penelitian ini meliputi : Analisa proksimat meliputi kadar air metode Gravimetri, (AOAC, 2005), kadar abu Metode Gravimetri (AOAC, 2005), kadar lemak Metode Soxhlet (AOAC, 2005) dan kadar protein Metode Mikro Kjeldalhl (AOAC, 2005).

Analisis yang digunakan meliputi analisis Parametrik untuk Analisa fisik (warna), data yang diperoleh disajikan dalam bentuk tabel dan grafik serta dilakukan analisis ragam (ANOVA). Apabila berpengaruh nyata, maka dilanjutkan dengan uji lanjut berdasarkan koefisien keragaman.

Data uji sensorik (penampakan, warna, tekstur, aroma dan rasa) dianalisis dengan uji statistika nonparametrik Friedman (Conover,1980). Jika hasil analisis yang menunjukkan pengaruh yang berbeda nyata maka dilanjutkan untuk uji lanjut multiple comparison.

\section{Prosedur Penelitian}

Prosedur penelitian meliputi pengolahan ikan patin menjadi surimi, pengolahan wortel menjadi Puree wortel dan pegolahan nugget dari bahan baku surimi dan Puree wortel.

Pembuatan nugget pada penelitian ini berdasarkan Pusat Pendidikan Kelautan dan Perikanan, 2012. Adalah sebagai berikut :

Adapun proses pengolahan nugget melalui beberapa tahap yaitu tahap pertama : Surimi ikan patin sebanyak 500 gram dimasukkan ke dalam food processor selanjutnya penambahan tepung terigu dan bumbu 
seperti garam, merica, bawang putih dan bawang Bombay yang sudah dihaluskan sebelumnya dan Puree Wortel sesuai perlakuan . Tambahkan tepung maizena sebagai bahan pengikat. Lalu aduk campuran selama kurang lebih selama 20 menit agar adonan benar-benar homogen. Tahap kedua : Setelah adonan homogen selanjutnya dilakukan pencetakan ke dalam Loyang. Tahap ketiga : Proses pengukusan adonan selama 30 menit setelah air mendidih $100^{\circ} \mathrm{C}$ sampai adonan tersebut kenyal dan terlihat mengembang. Tahap Keempat : Pendinginan adonan nugget dengan cara diangin-anginkan selama 15 menit. Pemotongan dengan ukuran 2x2x1 cm. Tahap kelima : Pencelupan ke dalam tepung roti yang sebelumnya nugget ikan terlebih dahulu dicelupkan ke dalam battering dan breading menggunakan terigu, air, garam dan tepung roti. Tahap keenam : Penyimpanan nugget ikan di dalam lemari pembeku suhu $-18^{\circ} \mathrm{C}$ yang dahulu, nugget ikan dikemas menggunakan plastik yang permebilitasnya kecil untuk mempertahankan mutu nugget ikan pada saat penyimpanan. Tahap ketujuh : Penggorengan nugget ikan menggunakan minyak goreng panas (suhu $170{ }^{\circ} \mathrm{C}$ ) selama 5 menit . Nugget ikan siap di analisa

\section{HASIL DAN PEMBAHASAN}

\section{Kadar Air}

Kadar air merupakan banyaknya air yang terkandung dalam bahan yang dinyatakan dalam persen. Kadar air juga salah satu karakteristik yang sangat penting pada bahan pangan, karena air dapat mempengaruhi penampakan, tekstur, dan cita rasa pada bahan pangan. Kadar air dalam bahan pangan ikut menentukan kesegaran dan daya awet bahan pangan tersebut, kadar air yang tinggi mengakibatkan mudahnya bakteri, kapang, dan khamir untuk berkembang biak, sehingga akan terjadi perubahan pada bahan pangan (Winarno, 1997).

Nilai rata-rata kadar air nugget dari surimi ikan Patin (Pangasius hypopthalmus) yang ditambahkan Puree Wortel berkisar antara 60,86\% sampai dengan 61,60\%). Hasil pengukuran kadar air nugget dari surimi ikan Patin (Pangasius hypopthalmus) disajikan pada Gambar 1.

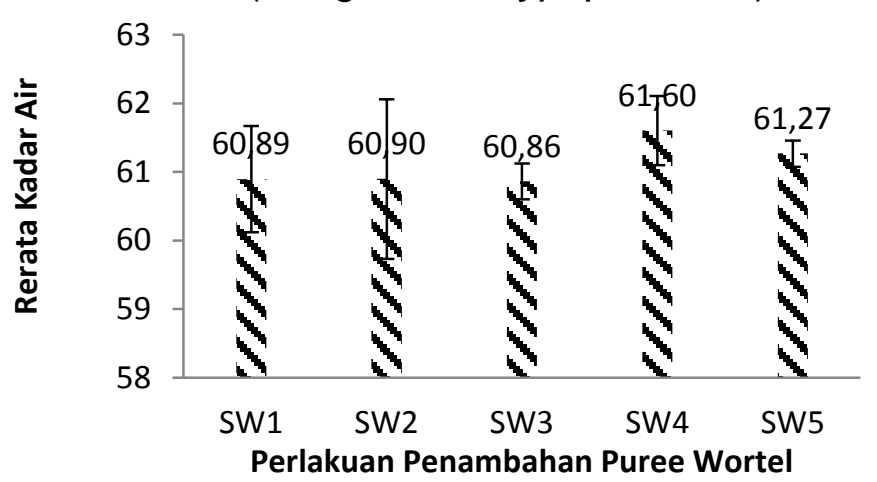

Gambar 1. Rerata Kadar Air 
Keterangan :

SW $1: 100 \%$ Surimi

SW 2 : 90 Surimi dan $10 \%$ Puree Wortel

SW $3: 80$ Surimi dan $20 \%$ Puree Wortel

SW $4: 70$ Surimi dan $30 \%$ Puree Wortel

SW 5 : 60 Surimi dan $40 \%$ Puree Wortel

Gambar 1, menunjukkan adanya peningkatan terhadap kadar air seiring bertambahnya konsentrasi Puree wortel. Berdasarkan data diatas dapat diketahui bahwa penambahan Puree wortel dapat meningkatkan kadar air nugget yang dibuat dari surimi ikan patin. Hal ini dikarenakan, wortel salah satu bahan makanan yang mengandung air cukup banyak yaitu setiap $100 \mathrm{gr}$ wortel mengandung 88,20 lg air. (Cahyono, 2002).

Selain itu, kadar air juga dipengaruhi oleh serat dalam wortel karena serat memiliki daya serap air yang tinggi, semakin tinggi kadar serat yang dihasilkan semakin tinggi pula kadar air yang dihasilkan.( Wibowo dkk, 2014).

Menurut Tala (2009) serat pangan memiliki daya serap air yang tinggi, karena ukuran polimernya besar, strukturnya kompleks dan banyak mengandung gugus hidroksil sehingga mampu menyerap air dalam jumlah yang besar.

Hasil analisis sidik ragam menunjukkan bahwa perlakuan penambahan Puree wortel pada nugget dari surimi ikan Patin (Pangasius hypopthalmus) tidak memberikan pengaruh nyata terhadap kadar air nugget tersebut..

\section{Kadar Abu}

Nilai rata-rata kadar abu nugget dari surimi ikan Patin (Pangasius hypopthalmus) yang ditambahkan Puree Wortel berkisar antara $1.84 \%$ sampai dengan 2.34\%). Hasil pengukuran kadar abu nugget dari surimi ikan Patin (Pangasius hypopthalmus) disajikan pada Gambar 2.

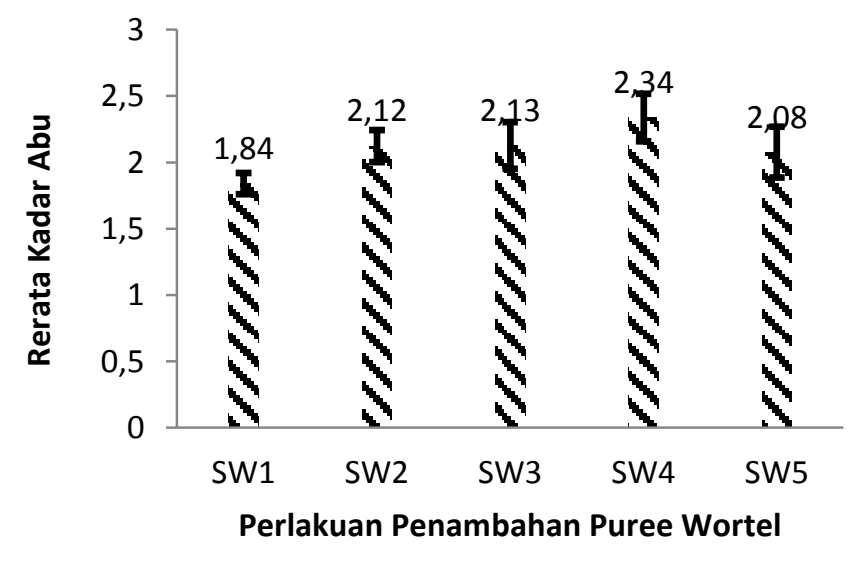

Gambar 2. Rerata Kadar Abu 
Keterangan :

SW $1: 100 \%$ Surimi

SW 2 : 90 Surimi dan 10\% Puree Wortel

SW 3 : 80 Surimi dan 20\% Puree Wortel

SW 4 : 70 Surimi dan 30\% Puree Wortel

SW $5: 60$ Surimi dan 40\% Puree Wortel

Gambar 2, menunjukkan adanya peningkatan terhadap kadar abu seiring bertambahnya konsentrasi Puree wortel.

Hasil analisis sidik ragam menunjukkan bahwa perlakuan penambahan Puree wortel pada nugget dari surimi ikan Patin (Pangasius hypopthalmus) memberikan pengaruh nyata terhadap kadar abu nugget tersebut. Hasil analisis uji lanjut beda nyata jujur (BNJ) terhadap kadar abu nugget.

Hasil uji lanjut BNJ menunjukkan bahwa perlakuan SW1 berbeda nyata dengan SW2,SW3,SW4 dan SW5. Nilai rata-rata kadar abu mengalami peningkatan dengan semakin tingginya penambahan Puree wortel. Semakin penambahan wortel dan semakin menurunnya konsentrasi surimi pada setiap komposisi dapat meningkatkan kadar abu nugget tersebut. Menurut Mahmud dalam Wibowo dkk (2014), kadar abu pada wortel sebesar $0,6 \%$ sehingga tinggi komposisi Puree wortel yang ditambahakan akan meningkatkan kadar abu nugget. Abu adalah sisa hasil pembakaran suatu bahan organik. Kadar abu suatu bahan berhubugan dengan kandungan mineral-mineral yang terdapat di dalam bahan tersebut. Menurut Sudarmaji dkk. (2007)

\section{Kadar Lemak}

Nilai rata-rata kadar lemak nugget dari surimi ikan Patin (Pangasius hypopthalmus) yang ditambahkan Puree Wortel berkisar antara $1.14 \%$ sampai dengan $2.23 \%$. Hasil pengukuran kadar lemak nugget dari surimi ikan Patin (Pangasius hypopthalmus) disajikan pada Gambar 3.

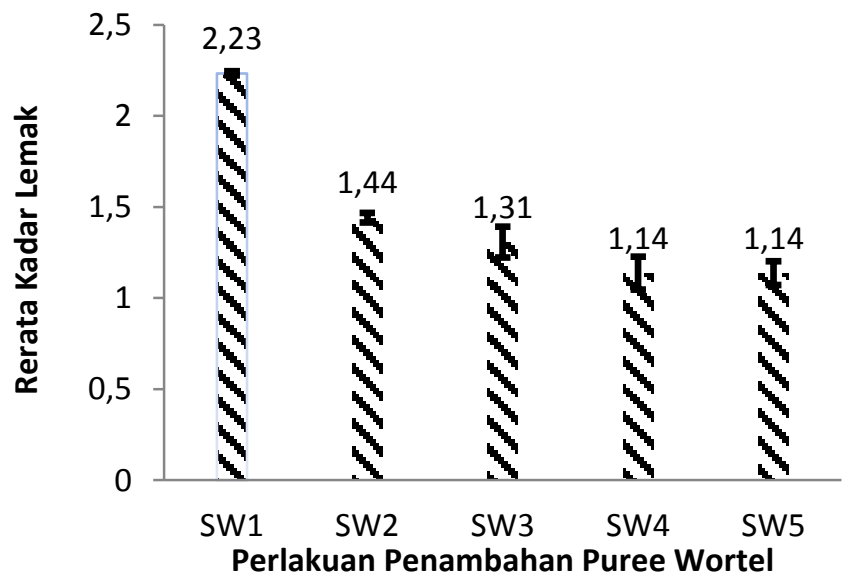

Gambar 3. Rerata Kadar Lemak

6 
Keterangan :

SW $1: 100 \%$ Surimi

SW 2 : 90 Surimi dan $10 \%$ Puree Wortel

SW $3: 80$ Surimi dan $20 \%$ Puree Wortel

SW $4: 70$ Surimi dan $30 \%$ Puree Wortel

SW 5 : 60 Surimi dan $40 \%$ Puree Wortel

Gambar 3, menunjukkan adanya penurunan terhadap kadar lemak seiring bertambahnya konsentrasi Puree wortel. Hal ini disebabkan lemak pada surimi ikan patin berkurang saat pencucian sehingga semakin sedikit komposisi surimi yang ditambahkan dan semakin banyak komposisi Puree wortel yang ditambahkan dalam pembuatan nugget maka nilai kadar lemak semakin menurun. Selain itu, karena pada proses pengolahan surimi dilakukan perendaman dengan air dingin sehingga lemak surimi ikan patin akan lebih membeku sehingga kandungan lemaknya lebih banyak berkurang. (Anwar dkk,2014).

Hasil analisis sidik ragam menunjukkan bahwa perlakuan penambahan Puree wortel pada nugget dari surimi ikan Patin (Pangasius hypopthalmus) memberikan pengaruh nyata terhadap kadar lemak nugget.

Hasil uji lanjut BNJ menunjukkan bahwa perlakuan SW1 berbeda nyata dengan SW2,SW3,SW4 dan SW5. Nilai rata-rata kadar lemak mengalami penurunan dengan semakin tingginya penambahan Puree wortel. Menurut SNI 01-6683-2002 kadar lemak nugget maksimal 20\% b/b sehingga kadar lemak nugget dari kelima perlakuan penambahan Puree wortel tersebut telah memenuhi standar mutu nugget. Kadar lemak tertinggi adalah perlakuan SW1 (perlakuan surimi 100\%) dan kadar lemak terendah pada perlakuan SW5 (perlakuan surimi $60 \%$ dan Puree wortel $40 \%)$.

\section{Kadar Protein}

Nilai rata-rata kadar protein nugget dari surimi ikan Patin (Pangasius hypopthalmus) yang ditambahkan Puree Wortel berkisar antara $4.49 \%$ sampai dengan $6.78 \%$. Hasil pengukuran kadar protein nugget dari surimi ikan Patin (Pangasius hypopthalmus) disajikan pada Gambar 4.

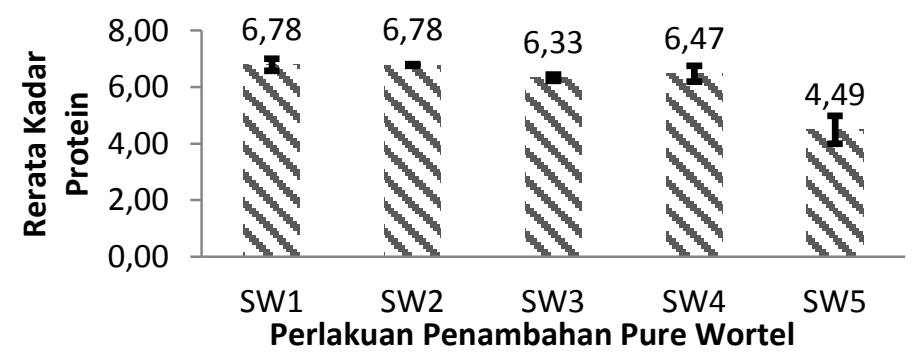

Gambar 4. Rerata Kadar Protein 
Keterangan :

SW $1: 100 \%$ Surimi

SW 2 : 90 Surimi dan 10\% Puree Wortel

SW 3 : 80 Surimi dan 20\% Puree Wortel

SW 4 : 70 Surimi dan 30\% Puree Wortel

SW 5 : 60 Surimi dan 40\% Puree Wortel

Gambar 4, menunjukkan adanya penurunan terhadap kadar protein seiring bertambahnya konsentrasi Puree wortel. Semakin tinggi konsentrasi penambahan pure wortel dan semakin menurunnya konsentrasi surimi pada setiap komposisi dapat menurunkan protein nugget tersebut.

Hasil analisis sidik ragam menunjukkan bahwa perlakuan penambahan Puree wortel pada nugget dari surimi ikan Patin (Pangasius hypopthalmus) memberikan pengaruh nyata terhadap proteimn nugget tersebut. Hasil analisis uji lanjut beda nyata jujur (BNJ) terhadap kadar serat kasar nugget

Hasil uji lanjut BNJ menunjukkan bahwa perlakuan SW1 berbeda nyata dengan SW2,SW3,SW4 dan SW5. Nilai rata-rata kadar serat kasar mengalami peningkatan dengan semakin tingginya penambahan Puree wortel.

Penurunan kandungan protein nugget ikan dari surimi ikan patin berbanding terbalik dengan peningkatan penambahan Puree wortel. Hal ini disebabkan, karena surimi ikan patin yang digunakan mengandung protein dan sebaliknya wortel mengandung protein yang rendah yaitu sebesar 0,93 gr/bb (USDA National Nutrient Database for Standard Reference, 2007), sehingga semakin tinggi konsentrasi Puree wortel yang ditambahkan dan semakin rendah surimi yang digunakan maka kandungan protein pada nugget semakin menurun. Desmelati dkk (2014), semakin banyak bahan baku yang digunakan pada pengolahan nugget, maka akan semakin tinggi kadar protein nugget tersebut dan begitu pula sebaliknya.

\section{KESIMPULAN}

Dari semua hasil diatas maka penulis dapat menyimpulkan bahwa nugget yang diolah dari formulasi $80 \%$ surimi ikan Patin dan $20 \%$ Puree wortel menghasilkan komposisi gizi yang memenuhi standar mutu nugget berdasarkan nilai kadar air 60,86\%, kadar abu 2,13\%, kadar lemak 1,31\% dan kadar protein $6,33 \%$. 


\section{DAFTAR PUSTAKA}

Alamsyah, Y. 2007. Aneka Nugget Sehat Nan Lezat. Agro Media, Jakarta.

Anwar, S., Suparmi \& Sumarto. 2014. Studi Reduksi Kadar Lemak dalam Pembuatan Surimi lkan Patin (Pangasius hypopthalmus) Dengan Perendaman yang Berbeda.

AOAC. 2005. Official Methods of analysis of the Association of Official Analytical Chemists. AOAC, Washington.

Cahyono, B. (2002). Wortel Teknik Budidaya dan Analisa Usaha Tani. Yogyakarta: Kanisius.

Desmelati, Sumarto, dan Meilin. 2014. Kajian Penerimaan Konsumen dan Mutu Nugget Udang Rebon (Acetes erythraeus). Jurnal Penelitian Pertanian BERNAS. 8 (2): 55-66.

[DKP Sumsel] Dinas Kelautan dan Perikanan Provinsi Sumatera Selatan. 2013. Buku Tahunan Perikanan Tangkap Provinsi Sumatera Selatan Tahun 2012. Palembang. DKP Sumsel.

Sudarmadji. S. dkk. 2007. Analisis bahan makanan dan pertanian. Liberty. Yogyakarta

Syamsir,E. 2008. Membuat Nugget Ikan. http://lmupangan.Blogspot.Com.

Tala, ZZ. 2009. Manfaat Serat Bagi Kesehatan. Medan: USU. hIm.2.

U.S. Department of Agriculture, Food Safety and Inspection Service. 2007. Ham Glossary - Ham and food safety fact sheet: 2007. Home page: http://www.fsis.usda.gov/factsheets/ham/ (Accessed 6/4/2013)

Wibowo, A., Hamzah F., \& Vonny.,SJ. 2014. Pemanfaatan Wortel (Daucus carota) dalam Meningkatkan Mutu Nugget Tempe. Jurnal SAGU Vol : 13. No. $2: 27-34$.

W. J. Conover. 1980. Practical Nonparametric Statistics. Second Edition, John Wiley \& Sons, New York.

Winarno, F. G. 1997. Kimia Pangan dan Gizi. Jakarta. Gramedia Pustaka Utama. 